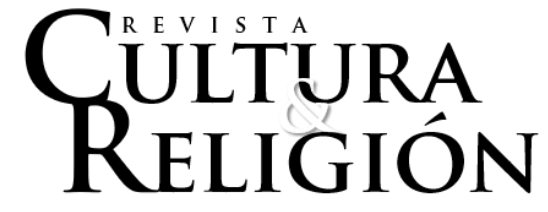

Vol. XV, No 1 (2021) pp. 259-298

Recibido: 10 de diciembre, 2020

Aceptado: 15 de mayo, 2021

\title{
LA RELIGIOSIDAD POPULAR DE AMÉRICA LATINA: UNA BISAGRA PARA COLOCAR LIVED RELIGION EN PROYECTOS DE DESCOLONIZACIÓN
}

\author{
Popular religiosity in Latin America: A linchpin for locating lived religion in \\ decolonization projects
}

\author{
Renée de la Torre* \\ CIESAS de Occidente \\ ORCID: 0000-0003-3914-4805
}

\section{Resumen}

Este artículo busca responder la pregunta, ¿qué ganamos o perdemos usando el concepto de religiosidad popular o el de lived religion? En América Latina se ha desarrollado una tradición de estudio de la religiosidad bajo el concepto de religión popular, término de carácter polisémico. Por un lado, inscrito en un campo lingüístico en el que el catolicentrismo lo cargó de significados de descalificación y degradación, pero también ha sido soporte de significados políticos y utópicos derivados de la teología de la liberación. Incluso, investigadores recientes consideran la religiosidad popular como un rasgo regional para entender la propia lógica para transitar a la(s) modernidad(es). Por otro lado, el concepto y la metodología de lived religion (religiosidad vivida) que busca detectar la experiencia religiosa desde la perspectiva de los individuos- ha venido ganando reconocimiento no solo en el mundo anglosajón, sino también en América Latina. En este ensayo se propone una 
lectura crítica para reconocer la necesidad de extender puentes entre lived religion y religiosidad popular, a fin de inscribir el reconocimiento de la experiencia religiosa en las tramas históricas que permiten colocar el conocimiento en un pensamiento de crítica poscolonial.

Palabras clave: lived religion, religiosidad popular, crítica poscolonial, pentecostalismo, neopaganismos.

\begin{abstract}
This article addresses the question: what do we gain or lose using the concept of popular religiosity or lived religion? A tradition of the study of religiosity under the concept of popular religion, a polysemic term, has developed in Latin America. On the one hand, it is inscribed in a linguistic field in which Catholiccentrism loaded it with meanings of disqualification and degradation. On the other, it has supported political and utopian meanings derived from liberation theology. Recent studies have even considered popular religiosity to be a regional characteristic that can be used to understand the unique logic for moving to modernity (or modernities). On the other hand, the concept and methodology of lived religion -which seeks to identify religious experience from individuals' perspective- has gained recognition in the Anglo-Saxon world and in Latin America. In this essay, we propose a critical reading for recognizing the need to build bridges between lived religion and popular religiosity in order to inscribe the recognition of religious experience in historical systems that allow the knowledge of a postcolonial critical thought to be located.
\end{abstract}

Keywords: lived religion, popular religiosity, postcolonial theory, Pentecostalism, neopaganisms. 


\section{Introducción}

La religiosidad popular es un rasgo característico de América Latina no solo por su colorido y vivacidad, sino sobre todo por ser una encrucijada histórica que mantiene la tensión del mestizaje cultural que ha tenido lugar en distintas etapas de la vida de este subcontinente. Este mestizaje resultó de un violento choque cultural y surgió de la imposición del catolicismo europeo y la resistencia indígena; y que posteriormente cohabitó con las religiones africanas. El culto a las imágenes de santos católicos aparentemente desplazó a los ídolos mesoamericanos, a las huacas andinas y a los oricha africanos, y conquistó el triunfo de una evangelización devocional. Aunque en la realidad, tanto el cristianismo como las cosmovisiones nativas y los oricha africanos han cohabitado durante siglos de manera simulada por sus practicantes y han sido tolerados por la institución bajo el manto de los santos, cristos y vírgenes católicos en un sistema de intercambios rituales por intercesiones milagrosas (Giménez, 1978; Marzal, 2005). Este sistema devocional, que comúnmente se reconoce como catolicismo popular (por no ser ortodoxo y por ser sincrético), se abre a la hibridación con nuevas matrices religiosas mediante la continua relaboración y apropiación no solo de fe, sino fundamentalmente mediante su resimbolización estética y su resignificación cultural, permitiendo así creativas y novedosas adaptaciones.

Muchas de las tradiciones que son hoy reconocidas como patrimonio cultural (tangible o intangible) están relacionadas con la religiosidad popular (como son las fiestas patronales, las peregrinaciones y sus santuarios, las danzas indígenas y de conquista, la medicina tradicional, los rituales animistas de los cultos afrolatinoamericanos, los ritos paganos e indígenas vinculados con la naturaleza, las tradiciones chamánicas, etc.). El sistema de religiosidad popular representó un resguardo de saberes y cosmovisiones negadas o desvalorizadas por el catolicismo, pero que no pudieron ser suprimidas. Pero hay que reconocer que, además, la religiosidad popular no solo resguarda la memoria del pasado, sino que se adapta a nuevas circunstancias, e incluso se ha 
convertido en el anclaje estratégico legitimador de lo nuevo que opera como línea de memoria para tradicionalizar nuevas narrativas religiosas y seculares que circulan en un mundo global más interconectado por los flujos culturales, generando toda suerte de transculturaciones y de hibridismos (Hervieu-Léger, 2005).

\section{La ambivalencia de sentidos y definiciones de la religiosidad popular}

No existe una sola definición sobre la religiosidad popular, y el término mismo puede tener muchos usos y sentidos contradictorios y opuestos entre sí. Puede ser tanto adjetivador de una religión degradada de la religión oficial o institucional; pero también, cuando se habla de la religión del pueblo, puede ser sinónimo de un horizonte liberador y por tanto representa una vía alternativa para acceder a los valores modernizantes de la sociedad (Mallimaci, 2020). A pesar de ello tiene un potente carácter heurístico, pues representa un umbral entre lo tradicional y lo emergente, pero habrá que tener precaución para usarlo de una manera adecuada.

Una primera acepción de religión popular puede tener un carácter peyorativo. Cuando se habla de catolicismo popular se inscribe dentro de un contexto lingüístico que descalifica a lo popular como una religión degradada, inculta, supersticiosa e inferior. Enmarcada en un campo religioso específico, el católico, donde se distinguen accesos diferenciados y desnivelados a los secretos de salvación entre un cuerpo de especialistas (sacerdotes, pastores) y los laicos, la religiosidad popular es la religiosidad practicada, no especializada, no ortodoxa, aquella que se refiere a la religiosidad de los laicos; es decir, de la "gente común y corriente", en contraposición con los especialistas, o sacerdotes que se sitúan en un campo de religión institucionalizado que constriñe los accesos a los secretos de la salvación a los seglares (Bourdieu, 1971).

La adjetivación negativa de la religión popular suele tener también una connotación clasista, que denomina lo popular como religión de los pobres en contraposición con la religión de las élites educadas (y a los primeros se les 
degrada con categorías de incultos, ignorantes y por ende supersticiosos). Como lo señala Frigerio (2018), en esta connotación clasista no solo se descalifica al otro interno, sino que se ignoran e invisibilizan las prácticas relacionadas con el esoterismo, el ocultismo, el curanderismo y la magia, muchas de las cuales fueron promovidas por gente de ciencia.

Por ello es necesario desmarcarnos de dichos sentidos que generan descalificaciones dentro de un mercado lingüístico ${ }^{1}$ que sitúa las categorías en relaciones y desniveles de poder al interior de las estructuras de clase y de las divisiones de competencias especializadas al interior del campo religioso. No obstante, sin caer en las adjetivaciones peyorativas es importante deconstruir su peso político en el campo religioso y lingǘstico en el que se inscribe la religiosidad popular para enfatizar "la tensión entre creyente y la institución y destacar la existencia de una instancia comunitaria ubicada entre el individuo y la organización oficial" (Morello, 2020, p. 58). Esa es la vía para deconstruir la religiosidad popular.

El adjetivo de lo popular es también polisémico (De la Torre y Martín, 2016). Una segunda acepción de la religiosidad popular es aquella que se refiere a la religiosidad del pueblo como una religiosidad liberadora de las opresiones. Este uso y sentido fue incorporado por la teología de la liberación y las Comunidades Eclesiales de Base, que revalorizan la religión de la mayoría y de los de abajo, pero no en el sentido peyorativo sino contrariamente como una reivindicación del cumplimiento profético para lograr el reino de Dios en la tierra. El pueblo, en este contexto, expresa la posibilidad de encarnar una teología profética en un sujeto colectivo que construye accesos alternativos a los beneficios de la modernidad (justicia, igualdad, libertad). No obstante, este

${ }^{1}$ La propuesta de mercado lingüístico de Bourdieu (1985) permite analizar los discursos y narrativas en un campo de relaciones de poder. Para este autor, los discursos cobran un valor específico en un mercado que, por un lado, impone categorías más o menos valorizadas: "imponen criterios de apreciación más favorables a sus productos" (Bourdieu, 1985, p. 41); por otro lado, dentro del campo opera una distribución desnivelada de competencias lingüísticas entre especialistas y no especialistas. 
uso de lo popular como agente "pueblo" en repetidas ocasiones también ha contribuido a mitificar una totalidad homogénea que guía utopías (Semán, 2008). Por ejemplo, derivado de la teología de la liberación se conformaron las Comunidades Eclesiales de Base ([CEB] pequeñas agrupaciones vecinales que retomaron el método ver-juzgar-actuar), que propiciaron una nueva conciencia crítica dirigida a la emancipación y la lucha por condiciones más justas para los pobres. Posteriormente estas experiencias desembocaron en distintos movimientos políticos (en 1971 se formó el movimiento Cristianos por el Socialismo, coalición para promover el socialismo en nombre del Evangelio, y en la década de 1980 surgió el Movimiento Cristianos Comprometidos con las Luchas Populares, que brindaba apoyo a los cristianos activistas).

El fermento politizador de las CEB impactó principalmente la participación de los católicos en los movimientos campesinos y urbanopopulares de las principales metrópolis latinoamericanas. Incluso alcanzó expresiones más radicalizadas que vinculaban a los católicos con la guerrilla en distintos países centroamericanos. No obstante, la centralidad de lo popular y su homogeneización en el sujeto pueblo también invisibilizó otras otredades internas que no fueron incluidas, como son las culturas indígenas, ${ }^{2}$ afroamericanas, ${ }^{3}$ feministas $y^{4}$ queers. ${ }^{5}$ El carácter político revolucionario de la

${ }^{2}$ El rescate de la teología india "trata de recuperar el caminar de Dios en el pueblo, el caminar de Dios en los símbolos, los ritos, los mitos que son las antiguas palabras de los indígenas, para descubrir así el rostro y el corazón de Dios para los indígenas" (Torner cit. en Morales, 2018, p. 78).

${ }^{3}$ La teología afrolatinoamericana ha tenido su mayor auge en Brasil. Esta teología reconoce la historia de esclavitud colonial, y rescata la cultura y las costumbres del pueblo afroamericano, revalorizando su fe vinculada a la práctica de los oricha. Por tanto, es una teología que establece diálogos entre las cosmovisiones africanas y cristianas y que crea puentes para generar una liturgia ecuménica entre el catolicismo y los terreros de candomblé (ver Andrade, 1998).

${ }^{4}$ La teología feminista, también conocida como ecología feminista, contempla una visión holística de la relación naturaleza, pobreza y derechos de la mujer, y emprende un proceso liberador en este triple terreno. Se conformó a partir de un grupo de mujeres que participaban en encuentros y proyectos teológicos, como fueron los casos de Beatriz Couch en Argentina, Julia Esquivel en Guatemala, Ivone Gebara en Brasil y Elsa Taméz en Costa Rica, quienes se pronuncian por una mayor participación de las mujeres en la jerarquía eclesial, pues consideran que, si la mujer estuviera más integrada a la iglesia, probablemente las reglas sobre la sexualidad y la reproducción serían diferentes. Esta teología ha tenido presencia en distintos 
teología de la liberación se centró en la pobreza, pero dejó fuera demandas populares que hoy buscan reivindicarse en novedosas teologías, como es el diálogo con la economía y la ecología, ${ }^{6}$ las pastorales de los migrantes y otras críticas poscoloniales al patriarcalismo. Las teologías siguen renovándose en América Latina, y esto no solo sucede en el terreno católico sino en proyectos ecuménicos e incluso en el medio evangélico (ver Panotto, 2014).

\section{Las espiritualidades: ni tan autonómicas ni tan individuales}

Para un uso desimplicado de dichos contenidos habrá que referirnos a religiosidad y no a religión para evitar caer en una visión esencialista, catolicocéntrica y eclesiocéntrica (Frigerio, 2007) que frecuentemente equipara la religión popular con el catolicismo popular, y que como señalé líneas arriba la reduce a una religión degradada o desviada de la religión oficial (Morello, 2020). Dicha precisión permitirá ser crítico con la idea del catolicismo monopólico, para no invisibilizar las cosmologías y creencias variadas que quedaron muchas veces inadvertidas bajo el manto de catolicismo popular (Frigerio, 2018), como son las cosmovisiones indígenas y de raíz africana, los

países latinoamericanos y ha retomado el derecho a las decisiones sobre sexualidad como bandera de su liberación (De la Torre, 2009).

5 Aunque la teología queer se inició en Estados Unidos y principalmente entre sociedades protestantes, se ha apropiado en América Latina como parte de una deconstrucción de la teología de la liberación latinoamericana. Su principal exponente es la argentina Marcella Althaus-Reid, "que busca el acercamiento a Dios de-generado a través de perversiones o caminos distintos. Con esto se refiere a la búsqueda personal de Cristo, quien debe ser separado de las formas en las que ha sido representado para pensarlo como marica y, no sólo eso, sino como marica pobre, como compañero de quienes creen en él desde sus prácticas disidentes. Esto constituye una propuesta de amor radical basada en la idea de una teología sexual" (González Ortuño, 2016, p. 290).

${ }^{6}$ Uno de los principales teólogos que hoy han sido retomados en las encíclicas del papa Francisco I es Leonardo Boff, quien propone una ética ecológica preocupada y comprometida con el rescate de la naturaleza y del ser humano, que valora la libertad humana y el diálogo entre la diversidad cultural como la mejor forma para generar conocimiento, y que entabla un novedoso diálogo con la ciencia holística y con sabidurías de otras religiones -especialmente con las orientales, las africanas y las amerindias. A la vez que esta nueva concepción biocéntrica se opone y es crítica del antropocentrismo, que ha permeado el pensamiento occidental al interior del catolicismo, también es un fermento crítico de la racionalidad instrumental propia del capitalismo que reduce su relación con la naturaleza y con el ser humano a meras mercancías (De la Torre, 2009).

Revista Cultura \& Religión Vol. XV, 2021 № 1 (enero-junio)

De la Torre, R. (2021). La religiosidad popular de América Latina: una bisagra para colocar lived religión en proyectos de descolonización. Revista Cultura \& Religión, 15 (1), 259-298 
espiritismos que tuvieron gran auge principalmente en Brasil (Camurça, 2018; Hess, 1989), las escuelas esotéricas (Wright y Ceriani, 2018), las nuevas espiritualidades holísticas y alternativas (De la Torre, Gutiérrez y Juárez, 2013), y el conjunto de heterodoxias religiosas de reciente aparición (Frigerio, 2018). Podemos considerar también el sentido holístico de la espiritualidad de la Nueva Era, que ha activado una nueva matriz de sincretismo en movimiento (como lo definió Amaral [1999]).

La espiritualidad de la Nueva Era en América Latina no solo ha contribuido a difundir las técnicas espirituales orientales basadas en el desarrollo del self y el sentido de la autonomía (Carozzi, 1999), sino que en su apropiación latinoamericana el camino de los buscadores de la fuentes de una espiritualidad holística y alternativa se ha encaminado al encuentro con la religación con lo ancestral, lo natural, lo mágico y lo espiritual, estableciendo intercambios culturales con tradiciones indígenas y populares (De la Torre, Gutiérrez y Juárez, 2013). Por una parte, es cierto que la búsqueda cosmopolita de saberes ancestrales e indígenas genera el fenómeno que Possamai (2015) llamó gentrificación de las tradiciones vinculadas con el chamanismo y la ingesta de psicotrópicos, y los rituales indígenas ligados a la sacralización de la naturaleza y los depósitos populares de tradiciones ancestrales. Pero, por otra parte, ha generado novedosos híbridos como son algunos circuitos de las espiritualidades de la Nueva Era, que se han descentrado de las espiritualidades orientales (principalmente el budismo y el hinduismo) y han emprendido búsquedas (como es el movimiento neonativista de Camino Rojo) en sabidurías chamánicas, plantas de poder, danzas vernáculas, cantos indígenas y medicinas ancestrales, a fin de recuperar su reconexión con lo espiritual, la naturaleza, los ancestros y la pureza. En estas búsquedas de sabidurías alternas a la modernidad capitalista recolectan bienes culturales que se hallaban sincretizados con las culturas tradicionales y las ponen en circulación en nuevos circuitos de espiritualidades holísticas, neopaganismos y de salud alternativa transnacionales. El efecto de estas circulaciones ocurre en varias direcciones. Contribuyen a su mercantilización como son las ofertas de salud alternativa, el 
turismo místico y espiritual, la industria del entretenimiento, la literatura de autosuperación, el coaching, pero asimismo genera sentidos de crítica poscolonial, como son los movimientos ambientalistas y las nuevas perspectivas de género que buscan generar formas de organización en hermandades despatriarcalizadas. Adicionalmente, activan el efecto de polinización cultural, dando origen a intercambios entre la sensibilidad de la Nueva Era y algunas culturas indígenas que experimentan dinámicas de reconfiguración de las identidades y las alteridades que demarcan las narrativas nacionales, patrimoniales, étnicas y de género dentro de los dos contextos históricos y culturales, ya sea para generar identidades neoindias: neomayas, neomexicas, neoincas, neotoltecas; o incluso para impulsar la etnogénesis, como es el caso de los guaraníes reconvertidos a la espiritualidad de la ayahuasca, caso estudiado por Rose y Langdon (2013) .

Muchas de estas espiritualidades son transversales a la religión popular, otras funcionan de manera autónoma, y otras más han surgido de procesos de decolonización que promueven el rescate y la valoración de los saberes y cosmovisiones vernáculas mediante la crítica, la resemantización y la decantación de los soportes tradicionales. Atender estos dinamismos permitirá apreciar y reconocer otras creencias y cultos (antiguos y nuevos) que se mantenían resilientes bajo la envoltura del catolicismo, e incluso reconocer diferentes ontologías que se disocian del sincretismo y que apelan a recuperar sus raíces originarias, fenómeno que está creciendo en esta región subcontinental.

\section{Lived religion: una opción desimplicada de contenidos y normas institucionales}

Un grupo de sociólogos estadounidenses (Ammerman, 2007; McGuire, 2008; Orsi, 2005, 2012) promueve el estudio de lived religion (religiosidad vivida o de la experiencia) como alternativa para sortear las cargas de sentido presentes en el uso de la religión popular, la cual opera de forma ambivalente 
tanto como etiqueta que descalifica a sus practicantes tratándolos de primitivos e ignorantes, así como un medio de "vigilancia de la religión" para mantener cierta obediencia y ortodoxia (Orsi, 2012).

El término lived religion se enfoca en la religiosidad de la vida cotidiana inscrita en las circunstancias reales de las personas que la practican de forma individual y no de las doctrinas y postulados teológicos. Estos autores reconocen en la religiosidad vivida una coherencia práctica, eficaz y funcional, y no la tachan de irracional o supersticiosa (McGuire, 2008). Estudiar la religiosidad desde la concepción práctica de sus practicantes no es una novedad en la antropología, y menos en la antropología latinoamericana. Distintos estudios que debido a su vastedad sería imposible de nombrar, lo han hecho ya. También existen -como veremos más adelante- definiciones de la religiosidad popular que claman por desdibujar clasificaciones binarias y por atender las contradicciones y combinaciones que no cuadran con los dogmas o teologías, que Suárez (2015) llegó a denominar como "creencias bisagras". Lo interesante de la visión de este autor es que coloca un puente de interlocución para la antropología en el debate sociológico, que tiende a producir narrativas teóricas con pretensiones más universales. Por otro lado, los estudios de lived religion han estado muy cercanos a la comprensión de las nuevas espiritualidades individualizadas y centradas en dominios privados de la vida doméstica y cotidiana, pero han descuidado la atención de sus impactos en el espacio público y en la recomposición de la secularización (Fedele y Knibe, 2020).

Un aporte original de esta metodología es su énfasis epistemológico en el estudio de las materialidades, de los cuerpos, de las emociones y de las sensaciones. Elementos centrales de la experiencia religiosa que han sido poco atendidos en el estudio de la religiosidad popular, que subraya más su atención en la producción de significados colectivos o comunitarios. Por ejemplo, Orsi (2005) argumenta que la experiencia religiosa se vive en prácticas corporeizadas, en tanto que Csordas (cit. en Olivas, 2021) concibe el cuerpo como el terreno existencial de la cultura y en específico de la experiencia religiosa. Por su parte Meyer (2014) comprende la importancia del estudio de 
las materialidades no como meros vehículos de significados, sino como producciones estéticas que generan significados, mientras McGuire (2016) propone atender las experiencias sensoriales generadas por ambientaciones, como son la meditación, el movimiento corporal, la tranquilidad, la visualización interior.

Hace un par de años un equipo de académicos latinoamericanos emprendió un estudio comparativo de religiosidad vivida en tres ciudades (Lima, Montevideo y Córdova) del continente, tras reconocer la pérdida del monopolio católico y el ascenso de la diversidad de formas de creer, pero de un creer bajo la fórmula de "creyentes a mi manera", una forma personalizada que combina tradiciones para establecer comunicación y relacionarse con lo trascendente en la cotidianeidad (Parker, 2008). Si bien su punto de partida fue retomar la metodología propuesta por Ammerman (2014), basada en recoger narrativas autobiográficas de las formas de vivir lo religioso en el ámbito cotidiano de la gente común y corriente, sus conclusiones resaltaron que los creyentes "constantemente incorporan nuevos contenidos, pero sin romper con la tradición" (Rabbia, Morello, Da Costa y Romero, 2019, p. 15).

\section{Propuestas de conectividad entre los anclajes y las movilidades}

Cabe reconocer que el término lived religion aporta un marco de neutralidad lingüística que permite sortear las cargas peyorativas vinculantes al uso de la religión popular en un mercado lingüístico específico. Además, es de considerar que los científicos sociales latinoamericanos debemos aprovechar que su inclusión en la discusión teórica anglosajona nos brinda una nueva plataforma de interlocución que antes no teníamos en el medio académico internacional, donde los estudios sobre religiosidad popular no eran mainstream en la discusión, siendo la secularización (como tendencia a la ausencia o disminución de religión) el tema central de esas investigaciones.

Pero, por otro lado, también se debe tener en cuenta que hay que ser cauteloso pues no se puede tomar como un enfoque único y totalmente 
novedoso. Su uso exige un esfuerzo de diálogo con las propuestas y hallazgos de los estudios sobre religiosidad popular (distinta a religión popular) para no perder la capacidad de análisis estructural que ubica a este hecho social en una trama histórica de reacomodos de larga duración entre religiones impuestas y cosmovisiones de resistencia, enmarcada en tensiones de clase y en dinámicas de poder institucional que redefinen los rejuegos y contrapesos entre las culturas hegemónicas y subalternas. De hecho, este esfuerzo ya fue emprendido por Morello (2020) para rescatar la "otra lógica" del catolicismo latinoamericano propuesta por Parker (1993 -que es proporcionalmente inversa a la jaula de hierro provocada por la modernidad instrumental en los países protestantes- y que permite atender los procesos de encantamiento de las modernidades periféricas como resultado de las articulaciones entre la religiosidad vivida y su repercusión en la vida pública. Esta discusión también fue considerada por Juárez, Gutiérrez y De la Torre (2020), quienes proponen una perspectiva bisagra entre la tradición popular y las experiencias religiosas subjetivas como metáfora para contemplar las conectividades entre las dinámicas de anclajes de continuidad y la movilidad de las nuevas formas de la religiosidad.

Concuerdo con Possamai (2015), quien señaló que el concepto de lived religion no suple al de religiosidad popular, pues el primero se identifica con procesos de producción y apropiación de espiritualidades sin iglesia e individualizadas que son de algún modo producidas por las industrias culturales en la era de la globalización. Por ello, propone hacer un esfuerzo por atender cómo las espiritualidades están llegando a lo popular, a la vez que apreciar la manera en que la religión popular está siendo gentrificada por las espiritualidades globales.

En la misma línea, De la Torre $(2012,2013)$ ha argumentado la necesidad de atender la religiosidad popular, pero cambiando la perspectiva tradicional de conservar el pasado o como mera fórmula folklorista por una perspectiva que repare su estudio en el entremedio (in-between) (Bhabha, 2002) y las formas sincréticas de la religiosidad popular y las reconocidas como 
nuevas formas de la religiosidad (Mardones, 1994), entre las cuales se consideran las matrices de espiritualidad de la Nueva Era, holística e incluso los neoesoterismos. La religiosidad popular -aunque es una reserva de resistencias de sistemas culturales- también es un lugar dinámico que se adapta a los cambios y es adoptado por las nuevas espiritualidades de la modernidad como anclaje e hilo de memoria. Esta concepción de "entre-medio" (in-between) genera un puente entre el concepto de lived religion y el de religiosidad popular:

En la religiosidad popular, aun en la actualidad, se están viviendo permanentemente los procesos de redefinición y reinterpretación del sentido práctico de la religión. No es un estuche vacío, sino un espacio multipracticado, es decir un espacio de encrucijada. Por un lado, la religiosidad popular se mantiene como lugar que se resiste al orden dogmático y sacerdotal, pues ahí se salvaguardaron las formas no ortodoxas (por ejemplo, las creencias indígenas y del mundo campesino) que los especialistas de las religiones descalificaron como magia, idolatría, superstición, etcétera. Pero a la vez se mantiene como el espacio en que constantemente se renuevan e instituyen nuevos sentidos culturales y de identificación (como pueden ser las espiritualidades new age y la neoesoteria). (De la Torre, 2013, p. X).

Quisiera agregar que la perspectiva individual, no institucional y cotidiana de las experiencias religiosas, debe ampliar su horizonte temporal y social para superar el dilema entre lo institucional y lo individual, rescatando las producciones de microcomunidades (como es la familia, el barrio, la calle, las asociaciones) y las mediaciones presentes en sus maneras de vivir la religiosidad. Es también necesario ubicar las experiencias individuales en el plano histórico para analizar su posición en entramados de poder (De la Torre, 2012). Pero sobre todo es necesario hacer un esfuerzo epistemológico que nos permita reconocer las experiencias religiosas vividas hacia una deconstrucción de categorías emanadas de relaciones de poder y resistencia histórica. 
Por su parte, las perspectivas de los estudios de religiosidad popular deben esforzarse por salir de los límites de las particularidades propias de las monografías locales para conectar sus análisis en ejes de comparación a escalas que superen lo micro y lo local. Ejemplo de estos esfuerzos interescalares es el proyecto colectivo transnacional Religiones Transnacionales (Relitrans), ${ }^{7}$ que se situó no en los casos sino en los procesos transversales de transnacionalización y relocalización de tres movimientos religiosos que experimentan intensos traslapes de fronteras: los movimientos de espiritualidades neoindias, las misiones evangélicas y las religiosidades afrolatinoamericanas. El otro ejemplo es el proyecto de Religión vivida en América Latina (Morello, 2020; Rabbia et al., 2019), que logró sortear lo individual y lo local al poner en perspectiva las entrevistas sobre biografías de la experiencia religiosa en un análisis comparativo entre ciudades, y cuyo análisis se vio beneficiado al construir ejes temáticos transversales para -sin perder las perspectivas de los actores religiosos comunes y corrientes- traspasar su particularidad y valorar las regularidades entre grupos sociales y nuevas tendencias y mediaciones en las recomposiciones de los universos creyentes.

\section{Hacia una redefinición de religiosidad popular en diálogo con lived religion}

A contracorriente de las teorías clásicas de la secularización de la sociología de la religión, en América Latina la modernidad no debilitó la religiosidad, sino que continúa siendo una región "saturada de religión" (Rabbia et al., 2019). Tampoco lo religioso perdió vigencia en el espacio público; por el contrario, la simbología religiosa se expresa constantemente en diferentes movilizaciones ciudadanas y escenificaciones políticas e incluso coloniza constantemente los espacios públicos (Mallimaci, 2020). Sumado a ello, lo religioso en América Latina ha representado una vía de accesos periféricos a diferentes modernidades (Casanova, 1994), proyectos democráticos,

${ }^{7}$ Véase los principales resultados en Argyriadis, Capone, De la Torre y Mary (2012). 
movimientos políticos, defensa de derechos humanos en regímenes autoritarios, revoluciones culturales, etcétera (De la Torre y Semán, 2021). La religión no solo apela al ala conservadora de la sociedad, sino también motiva proyectos progresistas. Por ejemplo, Mallimaci (2017) explica cómo constantemente los espacios públicos son colonizados por la simbología religiosa, Toniol (2015) demuestra cómo las espiritualidades son complementarias al sistema público de salud y Wright y Ceriani (2018) argumentan cómo las heterodoxias espiritistas y ocultistas que se han desarrollado en América Latina desde el siglo XIX van de la mano de la ciencia.

Parker (1993) explicó que la religiosidad popular funciona en América Latina con "otra lógica" a la que funciona la religiosidad en muchos países de Europa y en Estados Unidos, cuyos comportamientos y tendencias se entienden bien con lógicas racionales, o bien, dogmáticas. Cuando la teoría de la secularización anunciaba que el predominio de la racionalidad instrumental propia del desarrollo moderno capitalista (tecnológico, capitalista, democrático y científico) - iría restándole relevancia a la religión y la conminaría a reducirla a un asunto meramente privado, en América Latina la religión católica, redefinida y reinterpretada por la teología de la liberación, era una vía propia para acceder a una modernidad que liberara a los pueblos de la opresión y que fuera una lámpara de sentido crítico para analizar sus propias estructuras de poder y transformarlas (De la Torre, 2008).

Es importante reconocer que la religiosidad popular no es una manera de pensar que obedezca a cánones racionalistas y occidentales, sino que es, ante todo: "otra manera de sentir, de pensar y de obrar, alternativa a la racionalidad ilustrada y al tipo de fe racionalizada que es su subproducto" (Parker, 1993, p. 192). Desde esta perspectiva, las dicotomías sobre las cuales se fincan las teorías de sociología religiosa no son útiles para entender la relación entre religión y dinámicas sociales. La religiosidad popular (siguiendo con Parker [1993]) es capaz de procesar las dos principales transformaciones actuales que incluyen: una pluralización de expresiones religiosas y los efectos de la modernidad en la secularización relativa de la cultura, debido a 
la creatividad religiosa del pueblo que -estimulado por la moderna tecnología informática- puede tender a recrear fervores religiososimbólicos mucho más proclives a lo festivo, lo multitudinario, lo mágico, lo místico y los anhelos mesiánicos, latentes en el potencial de protesta implícita o abierta- del simbolismo popular. (Parker, 1993, p. 145).

Esta otra lógica fue definida por el filósofo Echeverría (2000) como ethos barroco latinoamericano que, además de proporcionar un estilo estético de saturación de elementos, ofreció una forma de asimilación cultural entre las cosmovisiones indígenas y la fe católica. En este sentido, los sistemas religiosos mal llamados paganos o populares no sucumbieron ante la espada católica gracias a su capacidad de simulación y resistencia: "la vieja matriz cultural no fue destruida, sino que se adoptó ella misma para contener y domesticar dentro de sí el sistema religioso foráneo y para hacer uso de elementos extranjeros para así continuar ofreciendo sus propias respuestas" (Griffiths, 1998, pp. 344-345). Esta dimensión se extiende hacia la lógica capitalista y la lógica posmoderna.

El barroco no es solo el arte de la repetición, sino un ethos que permite "que lo antiguo se reencuentre justamente con su contrario, en lo moderno" (Echeverría, 2000, p. 44). Este ethos brinda "continuidad en la discontinuidad histórica y se practica y ritualiza en el mundo de vida" (Echeverría, 2000, p. 47). Por un lado, en apariencia durante la Colonia se impusieron las imágenes de devoción católica, pero a la vez se practicó una resistencia indígena basada en asimilar las apariencias (las formas) y mantener de forma simulada o velada sus propias deidades y cosmovisiones. El barroco no es solo un rasgo de la historia colonial, sino que continúa hasta nuestros días como una vía para entrar y salir de la posmodernidad (Gruzinsky 1990), e incluso podemos reconocer un ultrabarroco vinculado a la videogracia, que vuelve a colocar el régimen de la imagen como sustento productor de la cultura y de los imaginarios religiosos (De la Torre, 2016). ¿Por qué es importante traer a colación el barroco en esta época posmoderna? La respuesta remite a que este permite concatenar las renovaciones de las tradiciones basadas en resignificaciones y resimbolizaciones dentro del movimiento conocido como crítica poscolonial. A 
diferencia del barroco, el ultrabarroco contemporáneo ya no se conforma con disimular los conflictos, sino que busca sacar a la luz aquellas ambivalencias contradictorias que desde el origen el mimetismo barroco buscó soterrar, borrar $\mathrm{y}$ asimilar.

Debemos pensar en términos de praxis dónde se articulan las contradicciones y esquivar la lógica de las oposiciones. En este sentido, un mismo símbolo o hecho religioso articula lo institucional con lo popular; las nuevas formas de la religiosidad con las formas tradicionales; el poder con su resistencia; los conservadores con los disidentes. Aquí vale la pena retomar la invitación de Bhabha (2002) de colocar nuestros estudios en el lugar donde se ubican los intersticios, las fronteras, las interacciones, en aquellos espacios de entremedio que "proveen el terreno para elaborar estrategias de identidad [selfhood] (singular o comunitaria) que inician nuevos signos de identidad, y sitios innovadores de colaboración y cuestionamiento, en el acto de definir la idea misma de sociedad" (Bhabha, 2002, p. 18).

Vale la pena precisar también que la religiosidad popular tampoco funciona a partir de una lógica institucional como la que sugiere Bourdieu (1971) en su propuesta del campo religioso. La división tajante entre sacerdotes y laicos practicantes no existe como tal, pues si bien los sacerdotes se reservan el uso exclusivo de ciertas liturgias y secretos de salvación, la religiosidad popular es también fuente de agentes expertos en la gestión de la fiesta, los santos y la peregrinación, como son los llamados "agentes paraeclesiales" especializados en gestionar la devoción en torno a los santos y vírgenes con autonomía del poder clerical (Suárez, 2008). Por ello más que estudiar campos especializados, debemos estudiar los espacios de intersección e interacción entre los campos (De la Torre, 2006), pues es ahí donde se libran las batallas y donde podemos apreciar los dinamismos.

Por otro lado, se ha considerado a la religiosidad popular como una expresión de la dinámica del sincretismo, que dio origen el choque cultural entre el catolicismo introducido por los conquistadores y las cosmologías nativas (indígenas), y posteriormente las religiones de origen africano que

Revista Cultura \& Religión Vol. XV, 2021 № 1 (enero-junio) 275

De la Torre, R. (2021). La religiosidad popular de América Latina: una bisagra para colocar lived religión en proyectos de descolonización. Revista Cultura \& Religión, 15 (1), 259-298 
llegaron con el esclavismo negro. La religiosidad popular tiene un origen sincrético que, como lo plantea Sanchis (2008), opera como matriz generativa de síntesis entre marcos de creencias diversas, la cual describe de la siguiente manera:

Una fe en forma de religión. Y es por eso que, cuando se implanta en un espacio dominado por anteriores instituciones religiosas, ella tiende a operar por medio de transmutaciones de lo que parece posible asimilar y resemantizar en su propia síntesis. Su auto-concepción como una "totalidad", "la católica", lo predispone a esa estrategia, pues ella tiene más vocación para fagocitar que para excluir. (Sanchis, 2008, p. 82).

De esta manera, la religiosidad popular nos permite atender la experiencia y coherencia individual (que aporta la perspectiva de lived religion con mayor precisión metodológica y una epistemología más horizontal que invita a atender la fe desde las perspectivas ordinarias del creyente). Pero esta perspectiva requiere analizarse inmersa en una continuidad cultural histórica (aportada por el estudio de la religiosidad popular), que lejos de representar únicamente la dominación y la resistencia, es una fuente de asimilación de lo nuevo y de actualización de la cultura heredada. Por ello no sorprende que desde la religiosidad popular latinoamericana hayan surgido expresiones políticas de actores sociales diversos que retoman los rituales y la simbología de la religiosidad popular para enarbolar movimientos religiosos de reivindicación de los derechos humanos, de género, ambientalistas, políticos e incluso económicos (que pueden ir desde la teología de la pobreza hasta la teología de la prosperidad promovida por diferentes grupos evangélicos). De ahí que propongo que los estudios de las religiosidades vividas, e incluso de aquellas reconocidas por Mardones (1994) como "las nuevas formas de la religiosidad" (producidas y experimentadas en instituciones modernas y fuera de las religiones), sean atendidas no solo en los contextos de la vida doméstica, sino recolocadas en las tramas históricas de la religiosidad popular que, en palabras de Ameigueiras (2020), resulta “ fundamental [para] tener en cuenta dicha condición de asimetría y desigualdad dichos aspectos simbólicos [que]

Revista Cultura \& Religión Vol. XV, 2021 №1 (enero-junio) 276

De la Torre, R. (2021). La religiosidad popular de América Latina: una bisagra para colocar lived religión en proyectos de descolonización. Revista Cultura \& Religión, 15 (1), 259-298 
adquieren una importancia central que demanda explicitar el carácter dinámico de las matrices y tramas que conforman las culturas populares" (p. 263).

Desde hace algunos años es posible advertir que aun en estos tiempos de movilidad convulsa (sea generada por migraciones, flujos de mercancías, deslocalización virtual, o por la tendencia a la autonomía de las experiencias religiosas que ocurren al margen de las iglesias) que desenraiza, desarraiga y translocaliza sentidos culturales, es en la religiosidad popular donde las nuevas formas de la religiosidad buscan su legitimidad, su reconexión con los hilos de memoria, y por tanto es ahí donde se negocian permanentemente los procesos de redefinición y reinterpretación del sentido práctico de la religión. En la religiosidad popular se confrontan las relaciones de dominación, de resistencia, pero también admite la innovación creativa e incluso la transgresión de su propio sistema, generando distintas tramas de relaciones de poder entre la iglesia oficial y los creyentes, como entre las relaciones de clase y los nuevos impulsos de generar críticas decoloniales (como son los nuevos activismos que emergen de la mano de nuevas espiritualidades de la feminidad, movimientos neoindios contra capitalistas, y movimientos hippies ambientalistas y globalifóbicos).

\section{Transversalidades que articulan la tradición y las nuevas formas de lo religioso}

Para atender las reconfiguraciones que vive la religiosidad popular contemporánea en América Latina, distintos investigadores han redirigido el interés de sus estudios desplazándolos hacia los espacios limítrofes donde se tocan las lógicas de las tradiciones populares con otras lógicas de producción de creencias trascendentales. $^{8}$

\footnotetext{
${ }^{8}$ Un excelente ejemplo es el libro Fronteras de lo sagrado (Flores y Seiguer, 2020), que se sale de los confines de lo meramente religioso para ubicarse en las áreas de intersección y en las zonas de indefinición entre campos donde se negocian y redefinen los sentidos de lo religioso.
} 
En principio se tiende a dejar de restringir su estudio a instituciones, comunidades creyentes y a campos especializados (lo cual no quiere decir que no existan, ni que no sean relevantes). Lo que se plantea es reconocerlos, y situar el estudio en las tramas de intersección que ocurren en las líneas intersticiales entre distintos sistemas religiosos (atendiendo modalidades que son transversales a las iglesias). A continuación, se exponen algunos ejemplos de los aportes dentro de esta óptica.

Desde hace algunos años, Semán (2008) ha propuesto que un elemento distintivo de la religiosidad popular es el sentido cosmológico, entendido como dispositivo de sentidos mágicos, del contacto con el mundo de los espíritus, de la comunicación con seres que habitan en otra dimensión, y del mantenimiento de la fe en milagros y creencias sobrenaturales que acompañan en el día a día las prácticas devocionales tanto de la religiosidad católica popular, como de expresiones evangélicas, esotéricas e incluso presentes en las experiencias espirituales de la Nueva Era. Para este autor, la perspectiva "popular cosmológica" incorpora la inmanencia y subordinación del mundo cotidiano encantado por una simbología de lo sagrado, lo mágico, lo sobrenatural y lo milagroso. Las características de la perspectiva cosmológica, que es holista y abarcadora, a su vez es transversal a diferentes religiones o sistemas de creencias, modelando contenidos de creencias y haciéndose presente en diferentes prácticas heterodoxas al cristianismo.

\section{Los santos: in-between de la religiosidad popular sincrética}

Manuel Marzal (2005) destacó la importancia de los santos en la religiosidad popular andina. Lo mismo podría decirse en otras regiones de América Latina. Su presencia es indiscutible no solo en los altares de los templos, sino en capillas y murales callejeros, en altares domésticos en hogares y lugares de trabajo, e incluso tatuados en la piel de sus fieles devotos. Los santos han sido y son figuras intermediarias entre las divinidades y los humanos, a la vez que son figuras que permiten representar a las fuerzas o 
divinidades. Los santos articulan el mundo terrenal de los vivos con los muertos, la vida visible con entes invisibles.

Como se señaló al inicio, a través de los santos se asimiló al catolicismo la idolatría que tanto los frailes querían combatir. Entonces, abundaron las imágenes y su veneración. Posterior a la época colonial y hasta nuestros días, los santos son una continuidad de las tradiciones votivas y devotas familiares, a la vez que experimentan constantes resignificaciones en torno a sus poderes e intervenciones, e incluso son constantemente re-estilizados para mantenerse al día. Las efigies de santos, vírgenes y cristos no solo representan la intermediación con deidades, sino que son considerados en sí mismos seres milagrosos que interceden para ayudar a los humanos. Los santos tienen poderes y son sensibles: se alegran, enojan o entristecen. Asimismo, tienen gustos que se corresponden con las ofrendas. Pero la relación con los santos también produce efectos, sensaciones y sentimientos en sus devotos (De la Torre y Salas 2020).

Victor y Edith Turner (2017) dieron cuenta de cómo el sistema iconofílico, propio del catolicismo popular, sitúa la fe en torno a las imágenes milagrosas (santos, vírgenes y cristos) que imponen sus significantes (su materialidad) como significado de lo sagrado, del poder milagroso y de la experiencia comunicativa. Se refieren a que los santos no solo evocan significados (como los símbolos naturales), sino que son reverenciados como artefactos con agencia milagrosa (con capacidad de interceder o castigar), capaces de intervenir en el destino de las personas (remediar problemas y proteger de riesgos y enfermedades, y reconvertidos en seres cuasihumanos con los cuales se comunican sus fieles [Turner y Turner, 2017]).

Los santos puedes ser considerados como imágenes in-between pues, como se explicó al inicio, se rearticulan antiguas resistencias de las cosmologías negadas por el cristianismo (cosmologías africanas e indígenas) con el catolicismo popular; pero además se actualizan transformando sus hagiografías en leyendas populares o resimbolizándolos para hacerlos más humanoides. La fe en los santos está inmersa en un sistema ritual de fiestas, 
peregrinaciones y procesiones vinculadas con la práctica de los exvotos para agradecer la intervención milagrosa del santo.

Una de las tradiciones que ha sido reapropiada popularmente es la de vestir santos. Esta práctica implica transformarles su personalidad y se les incorpora como miembros de grupos de identidad o movimientos políticos específicos. Por ejemplo, Maximón (un santo maya sincrético de Guatemala) puede transfigurarse de una deidad indígena a su versión mestiza de San Simón, así como en finquero e incluso se puede reconvertir en un soldado yanqui para identificarse con los guatemaltecos que emigraron a Estados Unidos (Pedrón Colombani, 2008).

En México, uno de los santos más vestidos es el Niño Dios o Niño Jesús. Una imagen que se deriva del culto al Santo Niño de Atocha (imagen del niño Dios que proviene de España) y que por tradición se festeja cada 2 de febrero, vistiéndolo de ropajes blancos y de encaje. Este ritual ha sido reapropiado en el medio urbano de la ciudad de México, donde los fieles cambiaron sus trajes festivos en atuendos de santos y ángeles (el más popular es el niño San Judas Tadeo); posteriormente, los vistieron con los uniformes de sus equipos preferidos de fútbol o como danzantes rituales. En la actualidad, la tradición se ha secularizado a tal grado que se adaptan los trajes a las circunstancias y necesidades de sus fieles. Por ejemplo, durante el 2019 se vistió de "guachicolero" cuando hubo escasez de gasolina y en 2020 durante la epidemia COVID-19 se diseñó el traje para transformar al Niño Dios en Niño Covid, vestido de doctor que trae una jeringa en la mano (que simboliza la vacuna). Ese año, el niño Covid fue el más vendido, pues los fieles lo asociaban con la protección contra el virus. La tradición se ha expandido a tal grado en la capital del país que debido a la proliferación de comercios especializados en la venta de trajes para Niño Dios ya se renombró la calle Talavera como "la calle de los Niños Dios".

Pero el culto al Niño Dios también ha sido vestido como guerrillero para transformarlo en un valiente combatiente de la Asamblea Popular de los Pueblos de Oaxaca (APPO, un movimiento político combativo que se enfrentó 
al ejército con la compañía y protección de una efigie vestida con boina del Che Guevara y una resortera). A esta figura se le llegó a conocer como el Niño APPO, y Margarita Zires (cit. en De la Paz Reyes, 2014) comentó que con eso el Niño se convirtió en "el niño del pueblo", que los acompañaba y protegía durante las barricadas nocturnas para no ser acribillados en la lucha.

Otra figura que no es vestida sino resimbolizada mediante recreaciones estéticas es la Virgen de Guadalupe que, sin dejar de ser la imagen de la madre de Dios, se convierte en madre de maquiladoras, en una obrera chicana, en una joven y moderna mujer feminista, en una guerrillera indígena del Ejército Zapatista de Liberación Nacional en Chiapas, o en Nuestra Señora de las Barricadas. La virgen puede ser recreada para un público juvenil en su acepción de virgencita plis, o bien, puede encarnar a la mamacita de Marilyn Monroe estampada en la tilma de Juan Diego. Puede ser morena e identificarse con los indígenas para asimilarse a la antigua diosa Tonatzin (Nuestra Madre de los mexicas) o representar a la Pachamama en los circuitos de espiritualidades neopaganas, o ser seleccionada en las cartas del tarot como una de las deidades femeninas que representa un poderoso arquetipo en los rituales de los circuitos de espiritualidad de la Nueva Era.

Esta vocación travestida y transgresora de la virgen de Guadalupe ya ha contagiado a otras imágenes de vírgenes como ha sido la Virgen de Luján (Argentina), a la que se le colocó la pañoleta verde del movimiento feminista que simboliza la exigencia feminista de despenalización del aborto en Argentina. Pero en torno a su representación también está presente el uso que han hecho los movimientos provida al elegir a la virgen y sus colores azul cielo y blanco como estandarte de la defensa por la vida, e incluso al blanquear la tez de Guadalupe, teñir sus ojos de azul y aclarar su cabello para convertirla en una virgen desindianizada y por tanto apropiada para la élite conservadora de México y rescatada de los usos populares. En torno a la Virgen se juega una estrategia de resimbolización de las imágenes que contribuyen a su politización.

Constantemente, el culto a los santos expresa una combinación entre continuidad de la tradición con una renovación de sus significados. En México,

Revista Cultura \& Religión Vol. XV, 2021 Nº 1 (enero-junio)

De la Torre, R. (2021). La religiosidad popular de América Latina: una bisagra para colocar lived religión en proyectos de descolonización. Revista Cultura \& Religión, 15 (1), 259-298 
San Judas Tadeo, patrón de las causas difíciles, ha sido en San Juditas el patrón de las causas ilegales. De aquí emerge un culto popular urbano principalmente entre sectores marginales. Este culto consiste en la apropiación de figuras del santo a las cuales cada fiel le monta un altar en casa y le agradece sus milagros colocándole collares y pulseras que testimonian su poder. San Judas se ha convertido en un santo de frontera que se asocia con la Santa Muerte, pero también con la Santería cubana, pues sus fieles consideran que en él cohabita Orunlá.

Santo Toribio Romo fue canonizado por Juan Pablo II como mártir de la persecución religiosa que tuvo lugar en México durante el período de 19261929. Sin embargo, ha sido resignificado como el santo protector de los migrantes indocumentados que se aparece para ayudar a cruzar la frontera o que intercede para brindarles protección de cara a las políticas de deportación que se ven expuestos en su residencia en Estados Unidos (De la Torre y Guzmán, 2010). En 2010 al tornarse complicado el retorno estacional de los migrantes a sus lugares de origen, estos dejaron de visitar su santuario, ubicado en Santa Ana de Guadalupe, municipio de Jalostotitlán, en la región de los Altos de Jalisco. Para continuar el culto, el santo y sus reliquias se tornaron transportables. Se diseñó una efigie de tamaño humano que contiene sus reliquias en el corazón del Santo y que cada año viaja desde Jalisco para visitar las parroquias de mexicanos asentados en el Oeste de Estados Unidos, destino en el cual en la actualidad es considerado un santo que acompaña las movilizaciones políticas de los indocumentados para exigir una reforma migratoria.

Otro aspecto es la reinscripción de nuevos santos populares en las tradiciones católicas: los santos bandoleros que protegen a los narcotraficantes (Gudrún Jónsdóttir, 2014), entre los cuales el más famoso es Jesús Malverde de Sinaloa, México. Otro santo popular es el Gauchito Gil, protector de transportistas en Argentina. También cabe consignar el culto creciente a las imágenes de figuras de la muerte que se asocian con el mundo de la ilegalidad y la violencia (la de la Santa Muerte en México y la de San La Muerte en 
Argentina). Estas imágenes no son aceptadas por los sacerdotes, y sus cultos aunque retoman el sistema tradicional católico son altamente transgresivos (Frigerio, 2016; Hernández, 2016; Yllescas, 2019). En medio de la deshumanización y la violencia en que viven amplios sectores sociales de América Latina funcionan como intermediarias entre el bien y el mal, dios y el diablo, la vida y la muerte. Tanto la Santa Muerte como algunos santos y vírgenes con sentido etnonacional son también frecuentemente reconvertidos en mercancías esotéricas que se venden en puestos de hierberías y botánicas, donde se adquieren ampliando su sentido religioso a prácticas de magia y ocultismo (Argyriadis, 2016; Chesnut, 2010).

A diferencia del mimetismo propio de las copias del barroco colonial, el instrumento de decolonización del posbarroco parece ser la transfiguración. No obstante, esta estrategia recurre al símbolo dominante, pero imprimiéndole una doble articulación: "es también el signo de lo inapropiado, una diferencia u obstinación que cohesiona la función estratégica dominante del poder colonial, intensifica la vigilancia, y proyecta una amenaza inmanente tanto sobre el saber 'normalizado' como sobre los poderes disciplinarios" (Bhabha, 2002, p. 112).

\section{El pentecostalismo popular latinoamericano}

El pentecostalismo popular latinoamericano es reconocido como la tercera ola del protestantismo por promover liturgias emocionales y extáticas basadas en la experimentación de los dones del Espíritu Santo (Martin, 1990). ${ }^{9}$ El pentecostalismo no es una iglesia, sino una corriente litúrgica que está desplazando al catolicismo en varios países y regiones de América Latina. En la actualidad es ya considerado una expresión autónoma de la religiosidad

${ }^{9}$ El pentecostalismo tuvo su origen en Estados Unidos de Norteamérica a principios del siglo $\mathrm{XX}$, pero después de un siglo de presencia en América Latina se puede ya hablar de un cristianismo latinoamericano, dado que su desarrollo no responde a una mera imposición imperialista, sino fundamentalmente a su asimilación cultural desde la religiosidad popular, a partir de la cual se está reformulando una nueva solidaridad con sentido de comunidad moral, diferente al sentido liberal e individualista propio del protestantismo clásico o histórico proveniente del mundo anglosajón.

Revista Cultura \& Religión Vol. XV, 2021 Nº 1 (enero-junio)

De la Torre, R. (2021). La religiosidad popular de América Latina: una bisagra para colocar lived religión en proyectos de descolonización. Revista Cultura \& Religión, 15 (1), 259-298 
popular, destacando que poco se parece al protestantismo bíblico y racional de las iglesias históricas que provenía del mundo anglosajón, ya que pone el énfasis en su carácter vivencial altamente emotivo y catártico de los dones del Espíritu Santo. Esto le resta centralidad a los fundamentos doctrinarios apegados a la tradición bíblica (siendo la Biblia lo único que compartía con los protestantes liberales y anglosajones) (Mansilla, 2006).

Se puede hablar entonces de un pentecostalismo popular latinoamericano que comenzó a desarrollarse desde principios del siglo XX, cuando diferentes congregaciones pentecostales crearon versiones híbridas a partir de las tradiciones populares locales. Al respecto, Garma (1987) destaca la etnización de misiones evangélicas con liderazgos indígenas que contribuyeron a resistir los cacicazgos locales, las que aportaron formas alternativas de organización política. Por su parte, en la selva amazónica surgieron versiones evangélicas que generaron movimientos mesiánicos que se autodenominaban descendientes de los israelitas (Marzal, 2002). Otros autores como Oro (2003) y Mariano (1999) resaltan que la aparente oposición radical de la Iglesia Universal del Reino de Dios era propiciada por su similitud con el animismo propio de los movimientos espiritistas afrobrasileños.

Otro punto de vista a destacar es el de Silveira (2007), quien da cuenta de cómo el pentecostalismo brasileño rescata los rasgos de las religones mágicas, taumatúrgicas y chamánicas. Desde Guatemala, Pedrón (2008) se centra en el entremedio del culto a Maximón, una deidad maya ambivalente que se suma a los santos católicos populares y que fue prohibida por los pastores evangélicos no solo por ser una práctica idolátrica, sino por ser considerado como figura que encarna al diablo y reconocerse sus poderes. Los fieles evangélicos, indígenas y ladinos dejaron de participar en las fiestas de Maximón, pero seguían rindiéndole culto de manera oculta (Pedrón, 2008).

Otros ejemplos de estudios sobr el pentecostalismo latinoamericano son el de Rodríguez (2010) y Mansilla (2019). La primera estudió una iglesia neopentecostal situada en un poblado de la Sierra de Zongolica, donde se asienta una comunidad nahua que establece similitudes taumatúrgicas de 
sanación entre los brujos indígenas y los pastores del Ministerio. Más recientemente, el segundo encontró nuevos sincretismos entre un movimiento neopentecostal colombiano y los aymaras que integran los carnavales del catolicismo popular. Estas caracterizaciones nos permiten identificar un pentecostalismo popular-indígena transversalizado por la perspectiva cosmológica holística, que se hace presente en la taumaturgia propia de los rituales de sanación mediante la recepción de dones del Espíritu Santo, pero fundamentalmente en el incremento de prácticas de liberación y exorcismo que mantienen una continuidad con la concepción del mundo de los espíritus que tanto proscriben: cultos indígenas y afro tachados de diabólicos, al tiempo que temen del avance de las ciencias ocultas como portales que conectan con fuerzas negativas. Su rechazo permea sus cultos, incrementando la práctica de los exorcismos y las liberaciones a quienes fueron practicantes de dichos cultos.

Una prueba de que podemos hablar de religiosidad popular evangélica pentecostal es la que nos brinda el think tank Pew Research Center, cuando destaca que:

Muchos latinoamericanos -incluidos porcentajes substanciales de católicos y protestantes- dicen adoptar creencias y prácticas a menudo asociadas con religiones afrocaribeñas, afrobrasileñas e indígenas. Por ejemplo, al menos un tercio de los adultos de cada uno de los países encuestados cree en el "mal de ojo", la idea de que ciertas personas pueden lanzar hechizos o maleficios que causan daño. Las creencias en la brujería y la reencarnación también están muy difundidas entre la identidad pentecostal. (Pew Research Center, 2014, p. 57).

El pentecostalismo popular urbano también ha mostrado un énfasis desmedido en lo que llaman una guerra espiritual contra el maligno, la cual orienta "una identidad combativa y ofrece una metáfora útil para embates ideológicos" (Freston, 1993, p. 117). De manera insospechada, la taumaturgia se ha desplazado hacia el espacio público e incluso hacia la política, donde los pentecostales libran dicha guerra espiritual contra el maligno. Por ejemplo, han interpretado que las exigencias de derechos y libertades de feministas son 
expresiones diabólicas de la mal llamada "ideología de género". Su combate lo han orientado a salir de los templos para participar en cruzadas provida y profamilia, e inclusive en emprender la conquista de espacios políticos en diferentes cámaras de diputados y senadores de países latinoamericanos desde donde combaten a los demonios.

Un estudio reciente sobre la guerra espiritual en Ciudad Juárez, ubicada en la frontera entre México y Estados Unidos, en el estado de Chihuahua, ciudad famosa por el narcotráfico, los feminicidios y la delincuencia, analiza cómo en algunas iglesias pentecostales de clases obreras esta situación de descomposición social ha ido de la mano de una acentuación de la guerra espiritual (Vázquez, 2021). Por un lado, define la religiosidad pentecostal como un pentecostalismo popular que retoma las creencias que explican las causas de las enfermedades, de la crisis social y de la corrupción política como un alejamiento de Dios y una intervención de las fuerzas demoniadas o del mal. Por otro lado, demuestra cómo la conversión no constituye una ruptura de su pasado religioso, sino una reformulación moral de su habitus cosmológico. Lo que Vásquez denomina magicalización de las representaciones pentecostales, atraviesa el habitus de los creyentes que profesaban religiosidades populares (como son el fidencismo, el culto a la Santa Muerte, espiritismos y esoterismos), las que son enfrentadas por los pastores por considerarlas puertas para que aniden los demonios.

La guerra espiritual que se libra contra el demonio y las fuerzas del mal se lleva a cabo en distintos niveles, donde se busca sanar el cuerpo individual (las enfermedades físicas y emocionales encuentran su explicación de origen y se produce la sanación por la liberación de demonios). En la escala política se convierte en una justificación de su participación moralizadora en las instancias de gobierno y en los espacios públicos (cárceles, escuelas, hospitales, calles, etcétera). Y en el plano social justifica la promoción de una actividad proselitista que descalifica al resto de las religiones por considerarlas portales por donde actúa el maligno (Vázquez, 2021). 
En esta misma línea, el neopentecostalismo popular latinoamericano ha experimentado cambios no solo de forma, sino de sustancia: se ha incorporado al mercado intensificando bienes religiosos con poderes mágicos a la manera de fetiches y amuletos para lograr la cura y el bienestar físico espiritual y material. En este caso puede mantener vigentes estructuras de poder colonial con nuevos ropajes. Distintas iglesias reconocidas por los académicos como neopentecostales han incorporado las tendencias del marketing, del espectáculo, de las modas y las tecnologías, que se legitiman con la teología de la prosperidad basada en alcanzar el éxito en la vida terrena (Mariano, 1999 ). Además, han incrementado ofertas de sanación cada vez más similares al mercado neoesotérico, en donde los objetos se convierten en talismanes de protección contra los malos espíritus y amuletos de la gracia y bendiciones que se adquieren mediante mercancías.

Los pastores de distintas iglesias neopentecostales se han reconvertido en predicadores al estilo de shows televisivos, y en sus ceremonias aprovechan para comerciar con excursiones a Tierra Santa, "el agua del río Jordán”, "piedras de la tumba de Jesús", "pan bendecido", "aceite milagroso de Israel”, "arena de la playa del mar de Galilea", "aceite del monte de los olivos", etc., que encuentran similitudes con las tradiciones vinculadas a las reliquias católicas. La mercantilización ha cambiado su misión de salvación por una teología de la prosperidad al incorporar la riqueza como signo de la gracia divina. La cultura mediática se ha introducido para ganar adeptos, transformando los códigos litúrgicos en escenas cada vez más asimiladas por el espectáculo pop, desplazándose la cultura de la palabra por la cultura de la imagen, y la razón por una religiosidad sensitiva (Mansilla, 2006). La magicalización también impregna muchos de los telecultos evangélicos (los más reconocidos son los de la Iglesia Universal del Reino de Dios, de origen brasileño, que promueve trabajos mediados por el Espíritu Santo para lograr salud, éxito en el amor y con el dinero. De esta manera, el fetichismo de las mercancías religiosas es transversal a diferentes sistemas religosos interconectados por los sentidos mágicos. 


\section{Apuntes finales}

La religiosidad sigue siendo una práctica extendida y con vitalidad cultural en la vida diaria de las personas y las comunidades de las clases populares de América Latina. No es una persistencia de un pasado agónico. Ello se explica en gran medida porque es un lugar bisagra que, por un lado, permite la permanencia de antiguas tradiciones coloniales, indígenas y africanas (que incluso fueron negadas o estigmatizadas por el cristianismo), pero que hoy en día siguen vigentes, arropadas bajo el sincretismo. Sin embargo, por otro lado son bisagra de las trasformaciones convulsas que se viven en la región.

Las tradiciones católicas, debido a su carácter iconofílico que aporta una libertad de transportabilidad, ensamblaje y resimbolización de las imágenes, abren una ventana a la reapropiación simbólica de los usos y contenidos de las tradiciones. La espiritualidad de la Nueva Era se reconecta con rituales y cosmovisiones indígenas, generando de este modo nuevos híbridos e incluso inusitados esencialismos. Por su parte, el pentecostalismo recupera la dramaturgia propia de los sistemas indígenas. En este sentido, la religiosidad popular es transversal a las diferentes manifestaciones religiosas y mantiene un hilo practicado (no imaginado) con la memoria, pero también permite que la tradición se actualice permanentemente, e incluso que no sea una oposición para transitar hacia la posmodernidad, de manera de construir sus propios accesos periféricos a la modernidad, así como para generar críticas, pero sobre todo, estéticas decoloniales. Se advierte entonces que al no estar sujeta a las normas eclesiales, la religiosidad popular brinda rangos de libertad para la autogestión y su constante resignificación y resimbolización.

Por su parte, el concepto de lived religion permite atender la religiosidad ordinaria y cotidiana sin prejuiciarla con visiones canónicas o doctrinales, pero tiene una orientación individualista que subraya las nuevas formas de lo religioso. Se ha propuesto aquí que es necesario separar lo religioso de la religión, así como reinscribir el estudio de la lived religion (religiosidad vivida) en el eje histórico de lo popular, como eje de tensiones acumuladas, que 
permite atender las pugnas y tensiones actuales, como son las relaciones de clase, las relaciones racializadas, los roles de género y los estigmas morales.

Otro elemento que merece rescatarse de la propuesta de lived religion es la centralidad en la atención de las materialidades, de los cuerpos, de las emociones y de las sensaciones que muchas veces fueron minimizadas como expresiones degradadas, en contraste con el estudio de la religión que privilegiaba las ideas, las teologías, las narrativas y los significados. En los ejemplos expuestos a lo largo del artículo se muestra cómo las estéticas (no solo iconográficas sino también taumatúrgicas) conllevan a transformaciones profundas de las formas y los contenidos de la religiosidad popular pentecostal conforme a los sistemas taumatúrgicos de las religiones vernáculas, y cómo la religiosidad sensitiva genera puentes (no cognitivos) emocionales para establecer continuidades entre sistemas culturales que parecieran opuestos y contradictorios.

Por otro lado, el valor heurístico que aporta el concepto de religiosidad popular es que es un espacio donde se negocian nuevas expresiones bajo formas tradicionales y donde nuevas narrativas se tradicionalizan. La religiosidad popular aporta un saber-hacer (los creyentes tienen un dominio simbólico ritual paraeclesial en torno a las imágenes) que permite la creatividad simbólica de nuevas apropiaciones y reformulaciones. Estas resignificaciones y resimbolizaciones se viven en la vida doméstica, pero también continuamente saltan hacia los espacios públicos arropando movimientos populares $\mathrm{y}$, en algunos casos, movimientos que transgreden las propias matrices nacionales o regionales de la diferencia cultural (Segato, 2007).

Por último, es necesario subrayar que el estudio de la religiosidad popular debe contemplar una metodología de la transversalidad del fenómeno, que más que dar cuenta de las normas que regulan fronteras de identidad, sea capaz de trazar los vectores mediante los cuales se articulan diferentes movimientos religiosos y las actividades religiosas que buscan redefinir la realidad social en otras esferas especializadas bajo lógicas producidas por la modernidad. Los vectores que conducen o articulan lived religion (la 
religiosidad vivida) con los ámbitos de acción pública nos llevan a lugares insospechados donde lo religioso se manifiesta y busca incidir en ellos. No basta con reconocerlos como fuentes de sensibilidad, de corporalidad, sino que hay que analizarlos en el eje de su sentido histórico, pues como señala Yountae (6 de marzo de 2020):

Utilizar el encuentro colonial entre los españoles y los pueblos originarios de América como marco de referencia para el estudio de la religión y la modernidad/colonialidad ofrece un punto de partida más eficiente para interrogar los supuestos epistémicos fundamentales inscritos en los marcos conceptuales-teóricos empleados en el estudio de la religión moderna. Este esfuerzo es un reto para desde América Latina deconstruir las categorías que invisiblizan las tramas de poder y dominación, a la vez que las experiencias creativas de apropiación. (s/p).

Hay que seguir los hilos coloniales de las nuevas transformaciones para entender los nuevos derroteros, las nuevas envolturas y los sentidos emergentes que hoy en día tiene el concepto de lived religion. Su estudio actual exige corrimientos de fronteras que permitan resituar el lugar de su reformulación, ya no restringida a los templos y las religiones, pero tampoco meramente delimitada a lo individual como sugiere el método de lived religion. Por tanto, es menester reconocer su vigencia entre límites y fronteras, donde por un lado se engarzan los nuevos sentidos producidos por el mercado, la ciencia, las tecnologías de la información, los flujos transnacionales y la globalización con prácticas mágicas, chamánicas e incluso espirituales; y detectar los anclajes donde se enraízan en los rituales y símbolos propios de la religiosidad popular. Decolonizar la experiencia religiosa es o debe ser un reto intelectual de los académicos latinoamericanos del presente. 


\section{Referencias bibliográficas}

Amaral, L. (1999). Sincretismo em movimento. O estilo Nova Era de lidear com o sagrado. En M. J. Carozzi (org.), A nova era no Mercosul. Petropolis: Vozes.

Ameigueiras, A. (2020). Religión, migración y desigualdad en la periferia urbana del Gran Buenos Aires. En V. Giménez (ed.), La religión ante los problemas sociales: espiritualidad, poder y sociabilidad en América Latina (pp. 259-282). Buenos Aires: Clacso.

Ammerman, N. (2007). Everyday Religion: Observing Modern Religious Lives. Oxford: Oxford University Press.

Ammerman, N. (2014). Sacred Stories, Spiritual Tribes: Finding Religion in Everyday Life. Nueva York: Oxford University Press.

Andrade, E. (1998). Existe um pensar teológico negro? En A. da Silva (org.), Existe um pensar teológico negro? (pp. 75-91). São Paulo: Paulinas.

Argyriadis, K. (2016). La Santa Muerte: ¿Un culto en consolidación? En A. Hernández (coord.), La Santa Muerte: espacios, cultos y devociones (pp. 31-64). Tijuana: El Colegio de la Frontera Norte.

Argyriadis, K., Capone, S., De la Torre, R. y Mary, A. (coords.) (2012). En sentido contrario. Transnacionalización de religiones africanas, latinoamericanas. Ciudad de México: CIESAS/IRD.

Bhabha, H. K. (2002). El lugar de la cultura. Barcelona: Manantial.

Bourdieu, P. (1971). Genèse et structure du champ religieux. Revue Française de Sociologie, 12(2), 135-167.

Bourdieu, P. (1985). Qué significa hablar. Madrid: AKAL.

Camurça, M. (2018). Changes in alternative religiosities in Latin America: from the New Age to flows of transnationalizations. International Journal of Latin American Religion, (2), 191-206. doi: https://doi.org/10.1007/s41603-018-0058-1

Casanova, J. (1994). Public religions in the Modern World. Chicago: Chicago University Press. 
Carozzi, M. J. (1999). Introducão. En M. J. Carozzi (org.), A Nova Era no Mercosur. Petropolis: Vozes.

Chesnut, A. (2010) Santa Muerte. La segadora segura. Ciudad de México: Ariel.

De la Paz Reyes, K. (2014). APPO, ejemplo de autonomía ciudadana. Universo, 14(581), s. p. Recuperado de https://www.uv.mx/universo/general/appoejemplo-de-autonomia-ciudadana/

De la Torre, R. (2006). La Ecclesia Nostra: el catolicismo desde la perspectiva de los laicos: El caso de Guadalajara. México: CIESAS/Fondo de Cultura Económica.

De la Torre, R. (2008). La Iglesia católica y la defensa de los derechos humanos en México. Tres obispos, tres pronunciamientos distintos. En L. Varguez (coord.), Religión y derechos humanos. Perspectivas y realidades múltiples (pp. 108-168). México: Universidad Autónoma de Yucatán.

De la Torre, R. (2009). Vigencia de las teologías latinoamericanas. Boletín de la Biblioteca del Congreso de la Nación, (124), 31-48.

De la Torre, R. (2012). La religiosidad popular como "entre-medio" entre la religión institucional y la espiritualidad individualizada". Civitas, 12(3), 506-521.

De la Torre, R. (2013). La religiosidad popular: encrucijada de las nuevas formas de la religiosidad contemporánea y la tradición (el caso de México). Ponto Urbe, 12(7), 1-26.

De la Torre, R. (2016). Ultra-baroque catholicism: Multiplied images and decentered religious symbols. Social Compass, 63(2), 181-196. Recuperado de http://scp.sagepub.com/cgi/reprint/0037768616629 299v1.pdf?ijkey=VNXkFr6Ct1y6TPy\&keytype=finite (Impact Factor:0.172 | Ranking:Sociology 132 out of 142)

De la Torre, R., Gutiérrez, C. y Juárez, N. (2013) (coords.). Variaciones latinoamericanas del New Age. Ciudad de México: Publicaciones de la Casa Chata. 
De la Torre, R., Gutiérrez, C. y Juárez, N. (2020). Religiosidad bisagra. Cotidianidad y experiencias de lo sagrado en el México contemporáneo. Ciudad de México: CIESAS.

De la Torre, R. y Guzmán, F. (2010). Santo Toribio de mártir de los Altos a Santo de los emigrantes. En M. Rodríguez-Shadow y R. Ávila (comps.), Santuarios, peregrinaciones y religiosidad popular (pp. 107-128). Guadalajara: Universidad de Guadalajara.

De la Torre, R. y Martín, E. (2016). Religious studies in Latin America. Annual Review of Sociology, 42, julio, 473-492. doi: 10.1146/annurev-soc081715-074427

De la Torre, R. y Salas, A. (2020). Altares vemos, significados no sabemos: sustento material de la religiosidad vivida. Encartes, 3(5), 206-226. doi: https://doi.org/10.29340/en.v3n5.141

De la Torre, R. y Semán, P. (eds.) (2021). Religiones y espacios públicos en América Latina. Buenos Aires: CALAS/CLACSO.

Echeverría, B. (2000). La modernidad de lo barroco. Ciudad de México: Era.

Fedele, A. y Knibe, K. E. (2020). Introduction: spirituality, the third cathegory in a gendered triangle. En A. Fedele y K. E. Knibe (eds.), Secular Societies, Spiritual Selves? The Gendered Triangle of Religion. Secularity and spirituality (pp. 1-29). Londres/Nueva York: Routledge.

Flores, F. C. y Seiguer, P. (2020). Fronteras de lo sagrado. Definiciones y límites de lo religioso en la Argentina. Buenos Aires: Ediciones Imago Mundi.

Freston, P. (1993). Protestantes e política no Brasil: da constituinte ao impeachment. (Tesis de doctorado). Universidad Estatal de Campinas, Instituto de Filosofía y Ciencias Humanas, Campinas, SP. Recuperada de http://www.repositorio.unicamp.br/handle/REPOSIP/279821

Frigerio, A. (2007). Repensando el monopolio religioso del catolicismo en la Argentina. En M. J. Carozzi y C. Ceriani (coords.), Ciencias sociales y religión en América Latina: perspectivas en debate. Buenos Aires: Biblos/ACSRM.

Revista Cultura \& Religión Vol. XV, 2021 N 1 (enero-junio)

De la Torre, R. (2021). La religiosidad popular de América Latina: una bisagra para colocar lived religión en proyectos de descolonización. Revista Cultura \& Religión, 15 (1), 259-298 
Frigerio, A. (2016). San La Muerte en Argentina: usos heterogéneos y apropiaciones del "más justo de los santos". En A. Hernández (coord.), La Santa Muerte: espacios, cultos y devociones (pp. 252-256). Tijuana: El Colegio de la Frontera Norte.

Frigerio, A. (2018). ¿Por qué no podemos ver la diversidad religiosa?: cuestionando el paradigma católico-céntrico en el estudio de la religión en Latinoamérica. Cultura y representaciones sociales, 12(24), 51-95.

Frigerio, A. (2019). La experiencia religiosa pentecostal. Revista Nueva Sociedad, (280), 47-54

Garma, C. (1987). Protestantismo en una comunidad totonaca de Puebla. México: INI.

Giménez, G. (1978). Cultura popular y religión en el Anáhuac. México: IISUNAM.

González Ortuño, G. (2016). ¿Cómo se vive una fe queer? Los retos de las teologías de liberación. Revista Último Andar, (29), 280-294.

Griffiths, N. (1998). La cruz y la serpiente. La represión y el resurgimiento religioso en el Perú colonial. Lima: PUCP.

Gruzinsky, S. (1990). La guerra de las imágenes. De Cristóbal Colón a 'Blade Runner' (1492-2019). Ciudad de México: Fondo de Cultura Económica.

Gudrún Jónsdóttir, K. (2014). Bandoleros santificados: las devociones a Jesús Malverde y Pancho Villa. San Luis Potosí: El Colegio de San Luis.

Hernández, A. (coord.) (2016). La Santa Muerte: espacios, cultos y devociones. Tijuana: El Colegio de la Frontera Norte.

Hervieu-Léger, D. (2005). La religión, hilo de memoria. Barcelona: Herder.

Hess, D. (1989). Dissobessing disobession: Religion, ritual and social science in Brazil. Cultural Anthropology, 4(2), 182-193.

Mallimaci, F. (2017). Modernidades religiosas latinoamericanas. Un renovado debate epistemológico y conceptual. Caravelle [en línea], (108), 15-33. doi: https://doi.org/10.4000/caravelle.2218

Mallimaci, F. (2020). Ciencias sociales y teologías: los pobres y el pueblo en las Teologías de la Liberación en Argentina. En V. Giménez (ed.), La 
religión ante los problemas sociales: espiritualidad, poder $y$ sociabilidad en América Latina (pp. 283-316). Buenos Aires: CLACSO.

Mansilla, M. (2006). Del valle de lágrimas al valle de Jauja. Polis [en línea], (14). Recuperado de http://journals.openedition.org/polis/5190.

Mansilla, M (2019) Neopentecostalismo aymara. Ponencia presentada en el Encuentro RIFREM, celebrado en junio, en Creel, Chihuahua, México.

Mardones, J. M. (1994). Para comprender las nuevas formas de la religión. La reconfiguración postcristiana de la religión. Navarra: Editorial Verbo Divino.

Mariano, R. (1999). Neopentecostais: sociologia do novo pentecostalismo no Brasil. Sao Paulo: Loyola.

Martin, D. (1990). Tongues of fire: The Explosion of Protestantis in Latin America. Oxford: Basil Blackwell.

Marzal, M. (2002). Tierra encantada: tratado de antropología religiosa de América Latina. Madrid: Trotta.

Marzal, M. (2005). Los santos y la transformación religiosa del Perú colonial. Lima: Comisión de Fe y Cultura de la Pontificia Universidad Católica del Perú.

McGuire, M. (2008). Lived Religion. Faith and Practice in Everyday Life. Nueva York, NY: Oxford University Press.

McGuire M. (2016). Sensing religion. Individual sensory experiences, socialized senses, and everyday lived religion in practice. Social Compass, 63(2), 152-162.

Meyer, B. (2014). Mediation and the genesis of presence: Toward a material approach to religion. Inaugural Lecture by Birgit Meyer. Religion and Society: Advances in Research, (5), 205-254.

Morales, J. (2018) El Congreso Indígena de Chiapas: un testimonio Jesús Morales Bermúdez, San Cristóbal de las Casas, Chiapas, Universidad de Ciencias y Artes de Chiapas.

Morello, G. (2020). Una modernidad encantada. Religión vivida en Latinoamérica. Córdova: Educc Editorial.

Revista Cultura \& Religión Vol. XV, 2021 №1 (enero-junio) 295

De la Torre, R. (2021). La religiosidad popular de América Latina: una bisagra para colocar lived religión en proyectos de descolonización. Revista Cultura \& Religión, 15 (1), 259-298 
Morello, G. y Rabbia, H. (2019). Introducción. En H. Rabbia, G. Morello, N. Da Costa y C. Romero (comps.), La religión como experiencia cotidiana: creencias, prácticas y narrativas espirituales en Sudamérica (pp. 9-27). Córdova: Universidad Católica de Córdova.

Olivas, O. (2021). Una mirada retrospectiva y nuevas reflexiones sobre los procesos de embodiment como paradigma y orientación metodológica para la antropología. Encartes, 4(7), 337-356.

Oro, A. (2003). A política da Igreja Universal e seus reflexos nos campos religioso e político brasileiros. Revista Brasileira de Ciencias Sociais, 18(53), 53-69.

Orsi, R. (2005). Between Heaven and Earth: The Religious Worlds People Make and the Scholars Who Study Them. Nueva Jersey: Princeton University Press.

Orsi, R. (2012). Material children: Making God's presence real through catholic boys and girls. En G. Lynch y J. Mitchell (eds.), Religion, Media and Culture: A Reader (pp. 147-158). Londres: Routledge.

Panotto, N. (2014). Descolonizar lo divino. Aportes para una teología poscolonial del campo religioso latinoamericano. Rosario: Centro de Investigaciones y Estudios en Teoría Poscolonial.

Parker, C. (1993). Otra lógica en América Latina. Religión popular y modernización capitalista. Santiago: Fondo de Cultura Económica.

Parker, C. (2008) Pluralismo religioso, educción y ciudadanía. Estado \& Sociedade, 23(2), 281-354.

Pedrón, S. (2008). El culto de Maximón en Guatemala. Trace, (54), 31-44. Recuperado de https://journals.openedition.org/trace/457

Pew Research Center (2014). Religion in Latin America. Widespread Change in a Historically Catholic Region. Washington: Pew Research Center.

Possamai, A. (2015). Popular and lived religions. Current Sociology, 63(6), 781-799. 
Rabbia, H., Morello, G, Da Costa, N y Romero, C. (comps.) (2019). La religión como experiencia cotidiana: creencias, prácticas y narrativas espirituales en Sudamérica. Córdova: Universidad Católica de Córdova.

Rodríguez, M. T. (2010). Vida y milagros. Neopentecostalismo en comunidades nahuas. Diálogo Andino, (36), 51-60.

Rose, I. y Langdon, E. (2013). Chamanismos guaraní contemporáneos en Brasil: un estudio de transfiguración cultural. Revista Colombiana de Antropología, 49(1), 105-127.

Sanchis, P. (2008). Cultura brasileira e religião... passado e atualidade. Cuadernos Ceru, 19, serie 2, 71-92.

Segato, R. (2007). La nación y sus otros. Raza, etnicidad y diversidad religiosa en tiempos de políticas de identidad. Buenos Aires: Prometeo Libros.

Semán, P. (2008). Cosmología holista y relacional: una corriente de la religiosidad popular contemporánea. En A. P. Oro (org.), Latinidade da América Latina: enfoques socio-antropológicos (pp. 291-318). Sao Paulo: Hucitec.

Silveira, L. (2007). El campo religioso brasileño: pluralismo y cambios sociales. Protestantismo y pentecostalismo entre los años 1970 y 2000. En C. Rivera y E. Juárez (eds.), Más allá del espíritu. Actores, acciones y prácticas en iglesias pentecostales (pp. 23-52). Ciudad de México: CIESAS- Ed. Casa Chata.

Suárez, H. J. (2008). Peregrinación barrial de la Virgen de San Juan de los Lagos en Guanajuato. Agentes para-eclesiales. Archives des Sciences Sociales des Religions, (142), 87-111.

Suárez, H. J. (2015). Creyentes urbanos: Sociología de la experiencia religiosa en una colonia popular de la Ciudad de México. Ciudad de México: Universidad Nacional Autónoma de México.

Toniol, R. (2015). Espiritualidade que faz bem. Pesquisas, políticas públicas e práticas clínicas pela promoção da espiritu alidade como saúde. Sociedad y Religión: Sociología, Antropología e Historia de la Religión en el Cono Sur, 25(43), 110-143. 
Turner, V. y Turner, E. ([1978] 2017). Iconophily and Iconoclasm in Marian pilgrimage. En K. V. Norget y M. Mayblin (eds.), The Anthropology of Catholicism (pp. 71-79). Oakland: University of California Press.

Vázquez, P. (2021). El pentecostalismo y la "guerra espiritual" en el campo religioso de Ciudad Juárez: un estudio de la experiencia cosmológica y la movilidad religiosa. (Tesis de para optar al grado de doctorado en Ciencias Sociales), CIESAS Occidente, Guadalajara, México.

Wright, P. y Ceriani, C (2018). Introducción. En P. Wright (ed.), Periferias sagradas en la modernidad argentina (pp. 9-26). Buenos Aires: Editorial Biblos/Culturalia.

Yllescas, A. (2019). Ver, oír y callar. La Santa Muerte durante el encierro. Ciudad de México: UNAM.

Yountae, A. (6 de marzo de 2020). Por una teoría descolonial de la religión. Diversa. Red de Estudios de la Diversidad Religiosa en Argentina. [Blog]. Recuperado de http://www.diversidadreligiosa.com.ar/blog/poruna-teoria-descolonial-de-la-religion/

* Doctora en Ciencias Sociales con especialidad en Antropología Social. Profesora investigadora, Centro de Investigación y Estudios Superiores en Antropología Social (CIESAS) de Occidente, en Guadalajara, México. Miembro nivel III del Sistema Nacional de Investigadores. reneedela@gmail.com 